LINGUODIDACTICA XXII

DOI: 10.15290/lingdid.2018.22.01

\author{
dr Olga Anchimiuk \\ Uniwersytet w Białymstoku \\ Wydział Filologiczny, Instytut Filologii Wschodniosłowiańskiej \\ tel. (85) 7457450 \\ e-mail: anchimiuk.olga@02.pl \\ ORCID ID: https://orcid.org/0000-0003-2421-5148
}

\title{
БОЛЬНЫЕ И БОЛЕЗНИ В ЖИТИЯХ СВЯТЫХ-ОТШЕЛЬНИКОВ
}

\section{STRESZCZENIE}

\section{CHORZY I CHOROBY W ŻYWOTACH ŚWIĘTYCH-PUSTELNIKÓW}

Choroby człowieka, zarówno fizyczne, jak i duchowe, zgodnie z chrześcijańskimi zasadami wiary związane są z jego grzechami. Przedstawianie tych chorób, a także cudowne uzdrowienia stanowią największą objętościowo grupę spośród wszystkich typów cudów w wielotomowym dziele «Житія святыхъ на русском языке, изложенные по руководству Четих Миней святителя Димитрия Ростовского». Badanie repertuaru toposów w literaturze hagiograficznej pozwoliło sklasyfikować cuda tego typu, a także opisać choroby, niepodlegające prawom tradycyjnej medycyny; ukazać teksty precedensowe, stanowiące punkt odniesienia dla cudownych uzdrowień.

Słowa kluczowe: żywoty świętych, cudowne uleczenia, teksty precedensowe

\section{SUMMARY}

\section{THE SICK AND ILLNESSES IN THE LIVES OF THE HERMIT SAINTS}

According to Christian dogmas, both physical and spiritual human diseases are due to personal sins. Presenting illnesses as well as miraculous cures constitutes the biggest group among all types of miracles presented in multi-volume work «Житія святыхъ на русском языке, изложенные по руководству Четих Миней святителя Димитрия Ростовского».

The analysis of a repertoire of topoi in hagiographic works has given an opportunity to categorize the miracles, describe illnesses which cannot be the subject to traditional medicine, show precedent texts that can be a reference for miraculous cures.

Key words: the lives of the saints, miraculous cures, precedent texts 
Здоровье, как и счастье, благополучие, удача, является одной из важнейших бытийных категорий и ценностей в народном мировидении. Здоровье - естественное и искомое состояние человека, это категория, противостоящая болезни и смерти, основа благополучия, условие вступления в брак и продолжения рода ${ }^{1}$. В Средние века медицина была развита слабо и для поддержания здоровья целительным магическим обрядам отводилась значительная роль. В XI-XII веках расцвел культ святых и к местам погребения стали стекаться тысячи паломников. Святым жертвовали дары, страждущие молили святого о помощи, стремились прикоснуться к какой-либо вещи, принадлежавшей святому. С XIII в. примерно половина всего пантеона святых считались патронами определённых болезней. В Католицизме «часть [тела] мученика, которая подвергалась глумлению, становилась знаком, атрибутом, который позволяет распознать святого среди равных той частью, которую он демонстрирует: глаза святой Луции или святой Отилии, внутренности святого Эразма, грудь святой Агаты или зубы святой Аполлины» ${ }^{2}$, так святой Луции молятся при болезнях глаз, святому Эразму при внутренних болезнях или при родах, святой Агате при болезнях груди, святой Аполине при зубных болезнях. В благодарность за исцеление больные несут Иисусу Христу, Божьей Матери и святым вотивный орган ${ }^{3}$ (это широко распространено в Католицизме). В Православии широко известна серебряная рука, изображенная на иконе «Троеручица», принесенная святым Иоанном Дамаскиным в дар Божьей Матери в благодарность за чудесное исцеление.

В «Житіях святыхъ на русском языке, изложенным по руководству Четих Миней святителя Димитрия Ростовского» чудеса-исцеления представляют собой самую объемную группу среди всех типов чудес ${ }^{4}$, рассматриваемых в житиях преподобных, являющихся отшельниками.

Напомним, что иудо определяется как «явление, противоречащее законам природы и не объяснимое ими, но возможное - по суеверным представлениям - вследствие вмешательства потусторонней силы» [НСРЯ], а также «по религиозным и мифологическим представлениям:

В.В. Усачева, Магия слова и действия в народной культуре славян, Москва 2008, s. 249.

2 Historia ciała, t. 1, Od renesansu do oświecenia, G. Vigarello (red.), przeł. T. Stróżyński, Gdańsk 2011, s. 65.

3 Вотивный - приносимый в дар божеству.

4 Встречаются чудеса - явления, чудеса - воскрешения, чудеса - пророчества. 
сверхъестественное явление, вызванное вмешательством божьей силы» [БТС]. Как видим, в известных современных толковых словарях толкование практически одинаковое - «сверхъестественное явление, вызванное вмешательством божественной / потусторонней силы», с пометками - «по религиозным и мифологическим представлениям». В толковых словарях описываются значения слова, и, разумеется, такие толкования не отражают множества признаков понятия чуда - типично христианского понятия, которое опирается на чудеса Христа, являющиеся одновременно его прототипом и ключом, позволяющим его объяснить ${ }^{5}$. В толковом словаре наиболее приближенном по времени создания к «Житіям святыхъ...», изданном Императорской Академией Наук в 1789-1794 годах, толкование слова чудо следующее: «Чудо, 1. Дъйствїе Божїяго всемогущества свыше естественнаго порядка» [САР], что значительно отличается от толкований современных словарях.

Описание чуда в агиографическом тексте не просто жанрообразующий элемент. Так называемые прижизненные чудеса - это облигаторный элемент всякого жития, так как чудеса «служили в качестве письменного подтверждения дара чудотворения святого, что было необходимым условием его официальной канонизации» ${ }^{6}$.

Христианский чудотворец не совершает чуда сам, от своего имени, через него реализуется свободный дар Бога. Именно поэтому при описании чудес агиографическая традиция ориентирует автора жития на уподобление евангельской истории ${ }^{7}$.

В словарном толковании чудотворец - святой, прославившийся даром творить чудеса [БТС]. Согласно словарю, синонимом слова чудотвореи является святой. То есть все святые могут быть чудотворцами, но не во всех «Житіях святыхъ...» и выбранных из них житиях отшельников есть описание чудес.

В одном из житий упоминается становление чудотворца: «Когда преподобному Макарію исполнилось сорок лют, онъ получиль отъ Бога даръ чудотворенія, пророчества и власть надъ нечистыми духами».

5 J. Bouflet, Historia cudów: od średniowiecza do dziś, przeł. K. Żaboklicki, Warszawa 2011, s. 62 .

6 И.В. Стародумов, Жанровая специфика повествований о посмертных чудесах подвижников и составе древнерусской агиографии. Дис. на соискание уч. степени канд.фил.наук, Омск 2009, s. 171

7 А.В. Растягаев, Житийная топика в прозе писателей XVIII столетия (Кантемир, Тредиаковский, Фонвизин), Самара 2009, s. 35.

8 Житія святыхъ на русском языке, изложенные по руководству Четих Миней святителя Димитрия Ростовского, Январь, s. 603. 
Следует напомнить, что основными болезнями Средневековья были туберкулёз, малярия, оспа, коклюш, чесотка, различные уродства, нервные болезни, абсцессы, гангрены, язвы, опухоли, шанкры, экзема, рожистое воспаление, дизентерия, тиф и холера. Но болезни, упоминаемые в «Житіях святыхъ...», отличаются от перечисленных. Такие недуги, как беснование, расслабление, а также различные тяжелые, но неопределенные недуги: «...впала в жестокую болезнь», «тяжкий недуг», «тяжкая болезнь». С этими и другими многочисленными недугами (болезнь вследствие падения с ломади, потеря зрения, бельмо на глазах, лихорадка, смерть детей без причины, рождение мертвых детей, бесплодие, гангрена головы, водянка, выпадение кусочков костей из ног, припадки и судороги, язвы, вывих ноги, тяжелье роды, хромота, немота, оцепенение, проказа, сильные повреждения ноги и др.) не лечит традиционная медицина. Поэтому больные шли к святым, чудотворцам.

Причинами болезней по религиозным представлениям являются грехи. Грех определяется как «нарушение в мыслях или действием воли Бога, воплощенной в нравственных предписаниях, требованиях религ. санкционированных норм поведения и образа жизни» [ХрЭС]. Семантические границы славянского слова грех значительно шире: «Грехом называется нарушение всякого закона, нормы, правила. Др.-рус. грбшити: не попасть, ошибиться, пропустить» [МСДРЯ] Этимология праславянского слова ( ${ }^{*}$ grěxъ) связана $\boldsymbol{c}$ греть, с первоначальным значением «жжение (совести)» [ЭтС] Святые помогают грешникам побороть их грех, и тем самым спасают их от болезней.

Следует заметить, что религиозные жанры производны от одного церковнославянского прототекста - Священного Писания, который представлен в них в виде прецедентных текстов и библеизмов. Именно он «оказывается тем смысловым ядром, силовое поле которого порождает новые смыслы и новые тексты» 9 .

Понятие прецедентный текст (ПТ) стало активно использоваться после выхода книги Ю.Н. Караулова. Основы же возникновения теории интертекстуальности были заложены еще в работах М.М. Бахтина, ему принадлежит термин «чужое слово», который определяет суть идеи интертекстуальности. Все слова человека делятся на «маленький мирок своих слов и огромный бесконечный мир чужих» ${ }^{10}$. Таким образом, «любой текст, любой дискурс представляет собой диалог - диалог со всей пред-

9 Н.Б. Мечковская, Язык и религия. Лекиии по филологии и истории религий, Москва 1998, s. 148.

10 М.М. Бахтин, Вопросы литературы и эстетики, Москва 1975, s. 347-348. 
шествующей и последующей культурой» ${ }^{11}$. По мнению Р. Барта: «Новый текст состоит из старых цитат. Части кода, формул ритмических моделей, фрагментов культурных языков и т.д. проходят через текст и перераспределяются в нем, так как всегда есть язык до текста и внутри его» 12 .

Также известны работы связанные с исследованием ПТ, В.В. Красных, Д.Б. Гудкова, В.Г. Костомарова, Г.Г. Слышкина и других.

По мнению Ю.Н. Караулова к ПТ можно отнести тексты, существующие до художественной литературы «в виде мифов, преданий, устнопоэтических произведений», а также «библейские тексты и виды устной народной словесности (притча, анекдот, сказка и т.п.) и публицистические произведения историко-философского и политического звучания» ${ }^{13}$.

Среди производных терминов, связанных с «прецедентным текстом», мы встречаем и «прецедентную ситуацию» (ПС), появлявшуюся в трудах Красных (1998); Гудкова (2000); Прохорова (2004). «Прецедентной ситуацией (ПС) мы называем некоторую реальную единичную ситуацию, минимизированный инвариант восприятия которой, включающий представление о самом действии, о его участниках, основные коннотации и оценку, входит в когнитивную базу лингвокультурного сообщества и знаком практически всем социализированным представителям этого сообщества» ${ }^{14}$.

Чудо - это разновидность события, следовательно ему присущи основные характеристики события. Исследованию понятия ситуащии и события посвящены работы Ю.Д. Апресяна, Н.Д. Арутюновой, А.В. Бондарко, В.Г. Гака, В.Е. Гольдина, В.З. Демьянкова, Т.М. Николаевой.

А.В. Плешакова, Исследовавшая фреймы «происшествие» утверждает, что в мире, все, с нарушением нормы, отображается в языке наиболее полно и разнообразно, а также рассматривает его как событие или ситуацию, под которой понимает фрагмент объективной действительности, отраженный в сознании говорящего и представленный набором характерных для него составляющих ${ }^{15}$. Этот же подход применим и к иуду, которое является необычным событием, которое трудно объяснить, противоречащее естественному ходу вещей [Фил Энц].

11 Е.В. Бобырева, Религиозный дискурс: иенности, жанры, языковые характеристики, Волгоград 2007, s. 51.

12 Р. Барт, Избранные работь. Семиотика. Поэтика, 1994, s. 124.

13 Ю.Н. Караулов, Русский язык и языковая личность, Москва 2007, s. 216.

14 Д.Б. Гудков, Прецедентная ситуация и способы ее актуализации, [w:] Язык, сознание, коммуникация, В.В. Красных, А.И. Изотов (red.), Москва 2000, s. 41.

15 А.В. Плешакова, Исследование фреймов «происшествие» на материале русских и английских текстов жанра «инбормационное сообщение», Дисс. На соиск. Звания к.ф.н., Саратов 1998. 
Следовательно, чудо в житиях святых является ПС.

Напомним ситуации чудесного исцеления, совершенные Иисусом Христом: исцеление сына царедворца (Ин. 4:43-54); исцеление расслабленного у овечьей купальни (Ин. 5:1-16); исцеление сухорукого (Мф. 12:9-14; Мк. 3:1-6; Лк. 6:6-11); кисцеление расслабленного в Капернауме (Мф. 9:1-8; Мк. 2:1-12; Лк. 5:17-26); воскрешение сына вдовы (Лк. 7:11-17); исцеление бесноватых в стране Гадаринской (Мф. 8:28-34; Мк. 5:1-20; Лк. 8:26-37); исцеление бесноватого в Капернауме (Мк. 1:21-28; Лк. 4:31-37); исцеление тещи Петра и многих больных (Мф. 8:14-15; Мк. 1:30-31; Лк. 4:38-39); исцеление прокаженного (Мф. 8:2-4; Мк. 1:40-45;Лк. 5:12-15); воскрешение дочери Иаира (Мф. 9:18-26; Мк. 5:21-43;Лк. 8:41-56); исцеление кровоточивой женщины (Мф. 9:20-22; Мк. 5:25-29; Лк. 8:43-48); исцеление слепого в Вифсаиде (Мк. 8:22-26); исцеление дочери хананеянки (Мф. 15:21-28; Мк. 7:24-30); исцеление бесноватого отрока (Мф. 17:14-23; Мк. 9:14-32; Лк. 9:37-45); исцеление иерихонского слепца (Мф. 20:30-34; Мк. 10:46-52; Лк. 18:35-43); исцеление слепорожденного (Ин. 9:1-38); исцеление десяти прокаженных (Лк. 17:11-19); исцеление глухонемого косноязычного (Мк. 7:31-37); воскрешение Лазаря (Ин. 11:1-57; Ин. 12:9-11).

Исследователь Г.Г. Слышкин выделяет «пять основных видов реминисценций, служащих средством апелляции к концептам прецедентных текстов: упоминание, прямая цитация, квазицитация, аллюзия и продолжение» ${ }^{16}$.

В.И. Карасик, с своей известной монографии «Языковой круг. Личность, концепты, дискурс», анализируя работу Г.Г. Слышкина, указывает, что под упоминанием автор понимает прямое воспроизведение языковой единицы, которая является именем текстового концепта или именем автора текста (напр., «Война и мир») Прямая цитация, в его понимании это дословное воспроизведение текста или его части языковой личностью в своем дискурсе. Квазицитация - воспроизведение всего текста или его части в умышленно искаженном виде. Аллюзия - это соотнесение предмета общения с ситуацией или событием, описанном в определенном тексте, без упоминания этого текста и без воспроизведения значительной его части, т.е. на содержательном уровне. Продолжение - упоминания этого текста и без воспроизведения значительной его части, т.е. на содержательном уровне. Продолжение трактуется Г.Г. Слышкиным как текстовая

16 Г.Г. Слышкин, Прецедентный тект: структура кониепта и способы апелляции к нему, [w:] Проблемы речевой коммуникации. Межвузовский сборник научных трудов, Саратов 2000, s. 64 . 
реминисценция, основой которой, как правило, служат художественные тексты, и используют которую профессиональные писатели ${ }^{17}$.

В исследованных житиях святых преподобных встречаются следующее речевое выражение ПС чуда-исцеления:

Это упоминание чуда

Она, подойдя и ставъ сзади, подобно кровоточивой, коснувщейся края одежды Господней (Мф. 9:20-22) - тайно прикоснулась къ иноческому одюянію, которое было на преподобномъ, и тотчасъ получила исцпленіе... ${ }^{18}$.

И прямая цитация

«Входя въ двери дома онъ сказаль:

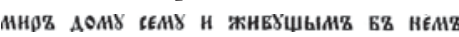

(Мфб. 10: 12). По слову Петра хозяинъ тотчасъ исцьлился отъ тяжкаго недуга...» ${ }^{19}$

Рассмотрев многочисленные фрагменты описания чудес-исцелений в преподобнических житиях святых-отшельников, мы установили, что их можно классифицировать по нескольким параметрам: способу излечения, результату чуда излечения, наличия прецедентного текста в пределах описания чуда. Способы излечения мы выделили следующие. Отречение от греха, принятие Святых Христовых Таин, созерцание святого (сам вид святого), речь святого (приветствие, при посещении больного). Самым распространенным методом излечения является молитва святого, которая присутствует во всех ситуация, однако не может не упоминаться в описании чуда исцеления. Многие ситуации исцеления связаны с непосредственным контактом святого с больным (это, кроме крестного знамения, различные прикосновения к больным местам, дуновения и др.). Разнообразны ситуации исцеления через материальные предметы (к которым мы относим ситуации исцеления не только святой водой, крестом, просфорой, веригами, жезлом, елеем, но также различными прикосновениями к одеждам святых). К практически единичным мы отнесли как отдельные способы исцеления следующие: святой берет на себя грехи больного, святой исцеляет пророчеством, а так же исцеление посредством того, что ребенку дается имя святого.

Результатом в целом является исцеление недуга, недуги же в житиях описаны наиболее распространенные из тех, которые человек не способен победить самостоятельно или с помощью врачевания. Иногда болезнь

17 В.И. Карасик, Языковой круг. Личность, конщепты, дискурс, Волгоград 2002, s. 35.

18 Житія святыхъ..., Январь, s. 327.

19 Там же, Іюнь, s. 259. 
неконкретно называется тяжким недугом или расслабленностью, но в большинстве своем как результат чуда указывается устранение конкретного недуга: слепоты, немоты, хромоты, язв, одержимости бесами, бесплодия и мертворождения.

Одним из параметров анализа фрагментов описания чудес является установление прецедентного текста.

Результат классификации представлен в таблице 1.

Как видно из описания существенным элементом чудесного исцеления является его временной параметр. Время осуществления чуда колеблется между мгновенным и отсроченным (как в случае исцеления по пророчеству).

Наиболее чудесным является мгновенное исцеление в результате применения то или иного способа. Однако иногда исцеление занимает определенное время. Вот как это передано в эпизоде чуда из жития святого Макария Александрийского: «Въ другой разъ къ преподобному быль приведенъ одержимый бюсомъ отрокъ, который быль весь опухшій оть водянки. Возложивъ на голову его правую руку, а на сердие лювую, преподобный сталь молиться Богу. Внезапно отрокъ вскричаль громкимъ голосомъ, и немедленно изб тпла его вылилось огромное количество воды. Посль сего тюло отрока пришло въ естественное состояніе, каким оно было раньше» ${ }^{20}$. И далее святой помазал больного святым елеем, окропил святой водой и запретил есть мясо и пить вино 14 дней.

О продолжительности лечения говорится в житии святого Макария Александрийского, лечение продолжалось двадцать дней: «Палладій вспоминаетъ объ одной благородной дтвици, которая въ теченіе многихъ лють была расслабленною и которую принесли къ преподобному Макарію из Өессалоникб. Преподобный исиплиль ее, помазуя въ теченіе двадиати дней святымъ елеемъ и молясь Богу и совершенно здоровою отпустил днвииу въ ея отечественный городъ. Посль своего исипленія она раздала по монастырямъ обильныя милостыни» ${ }^{21}$.

20 Там же, Январь, s. 639.

21 Там же. 


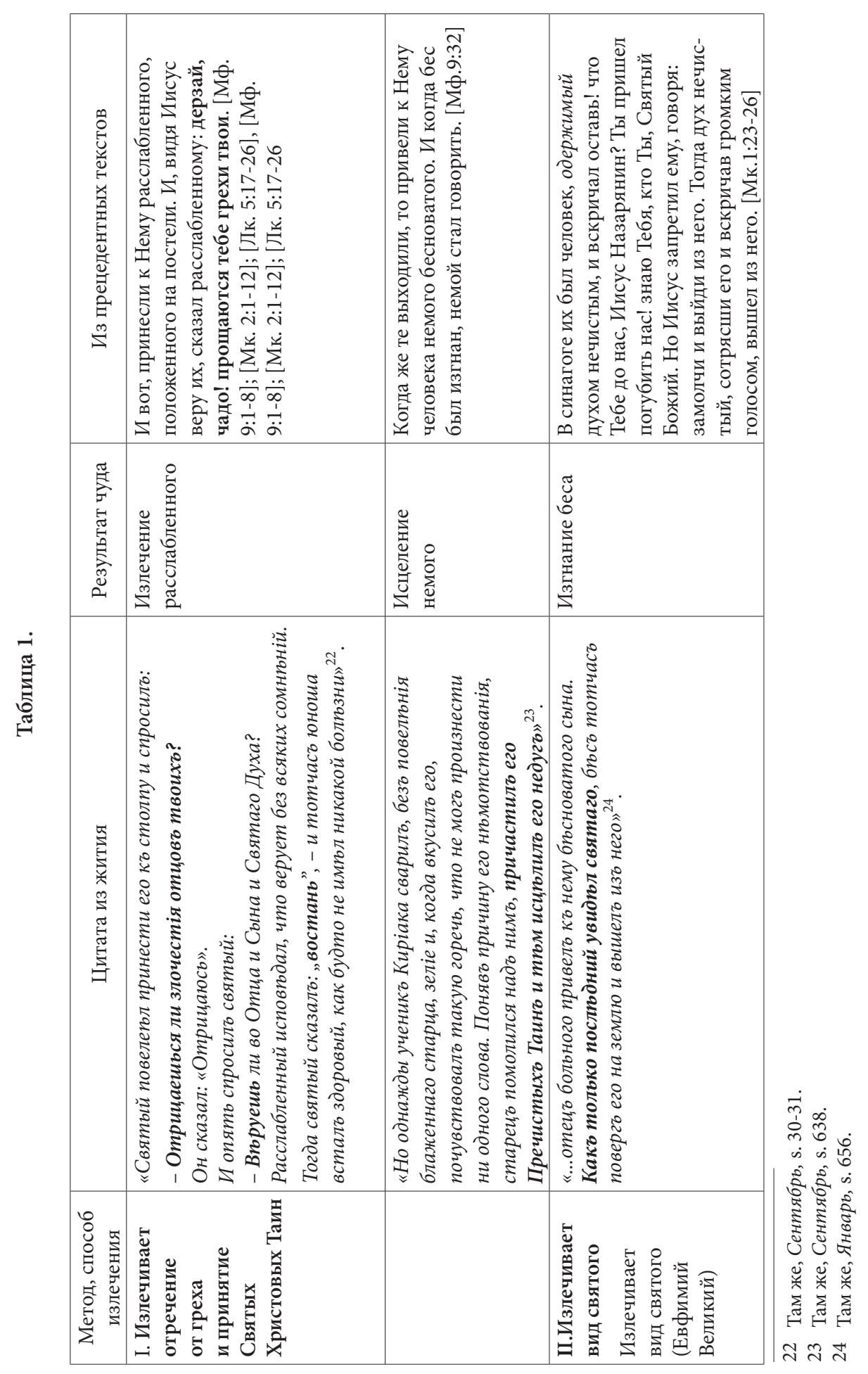




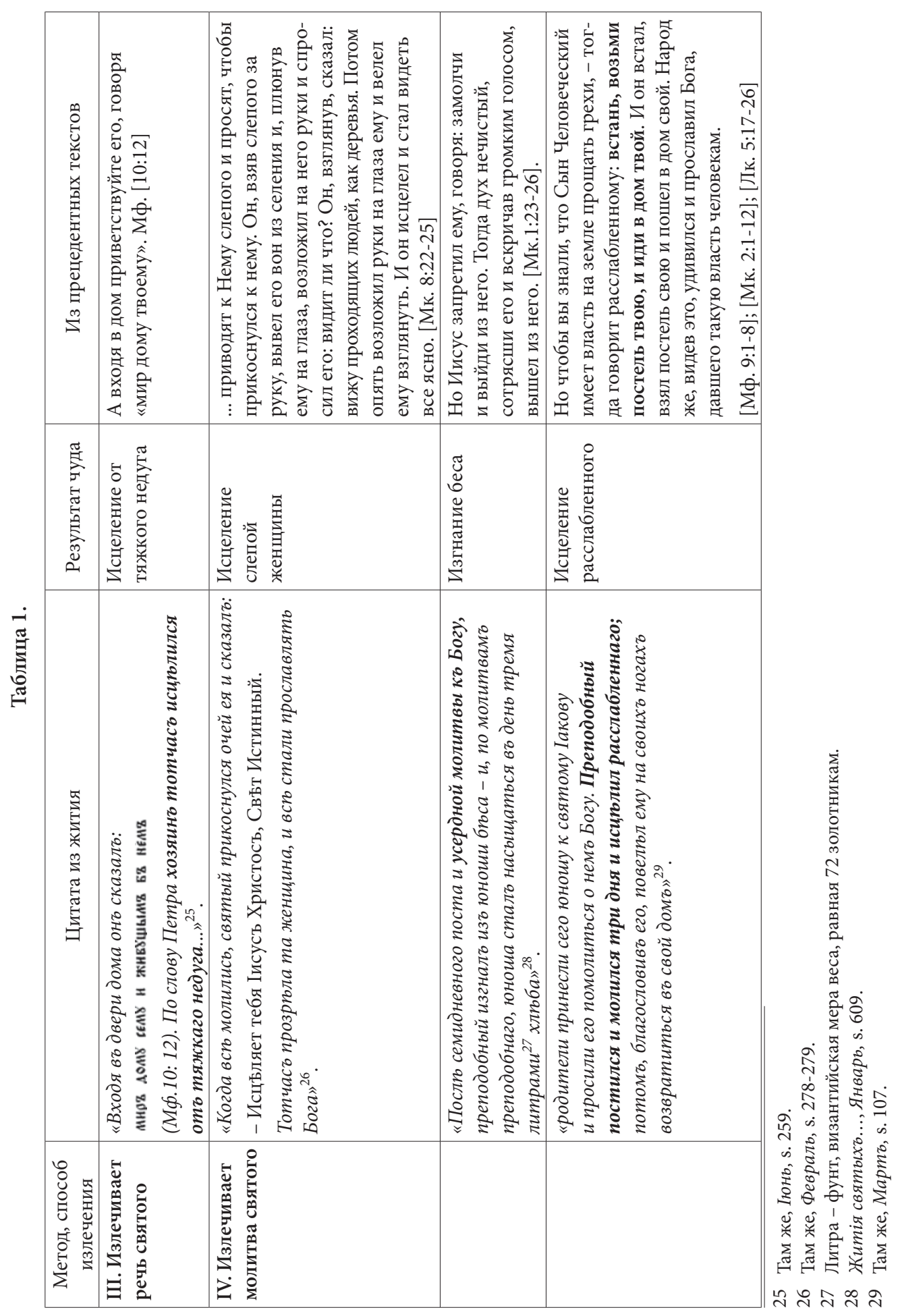




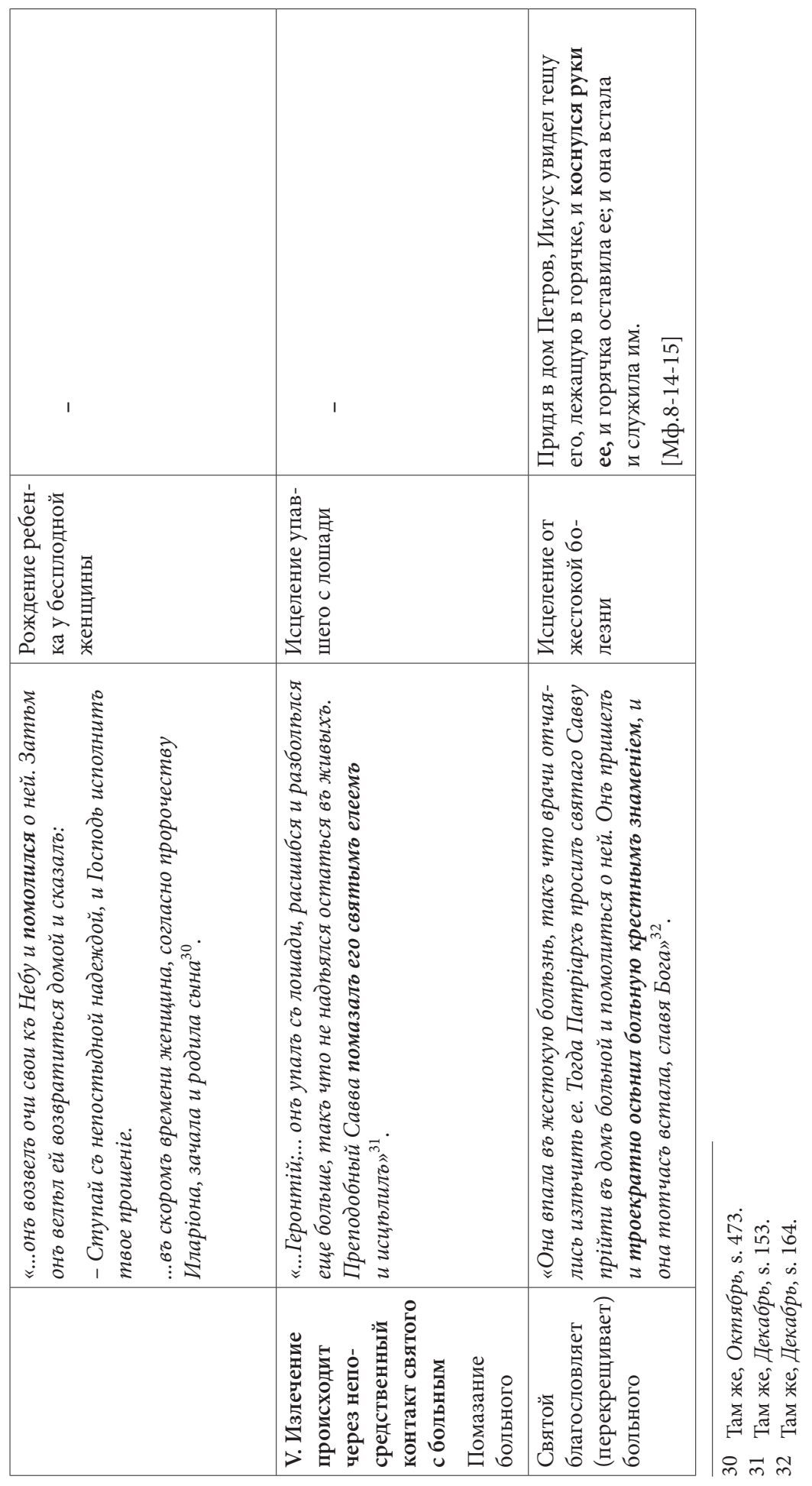




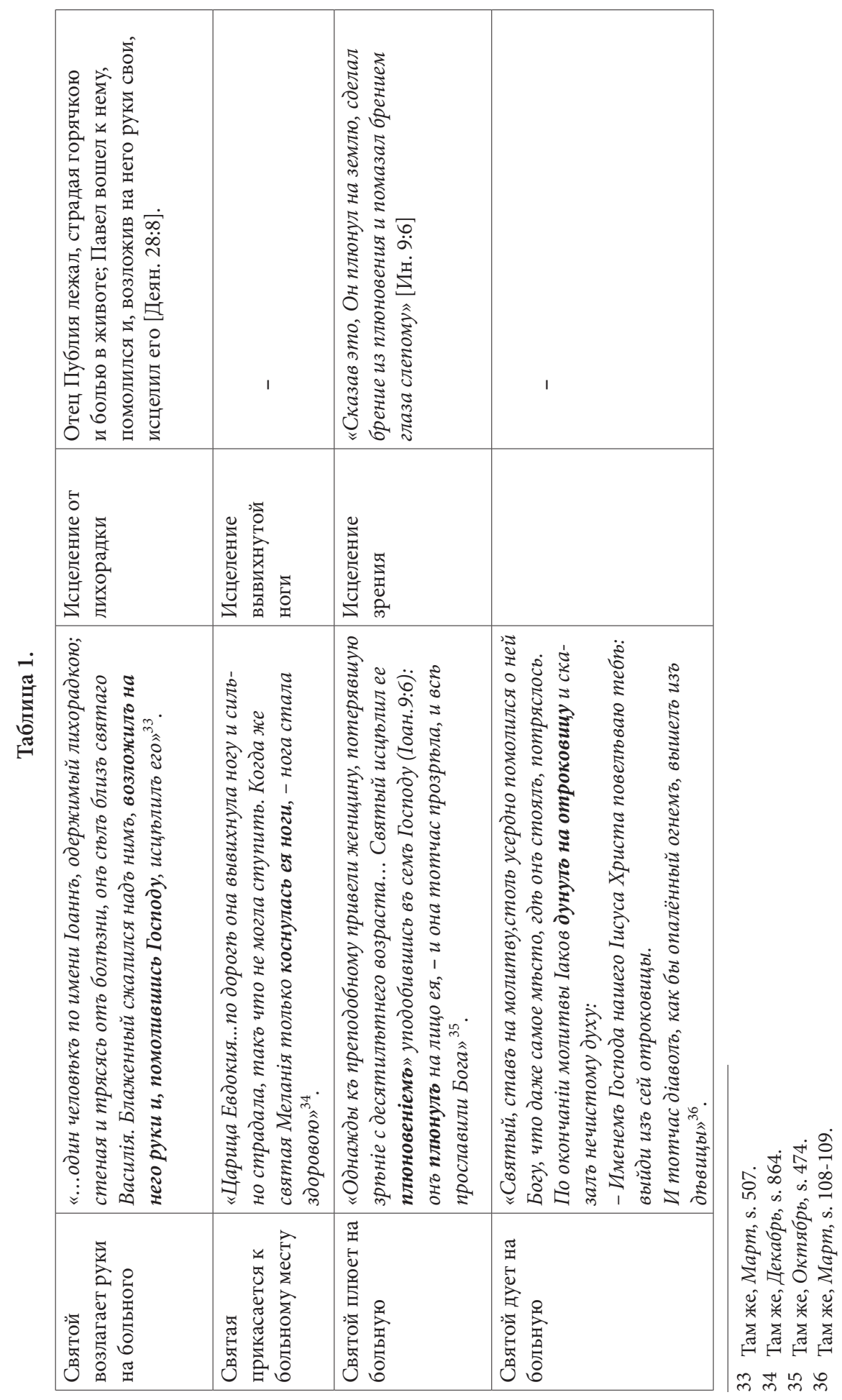




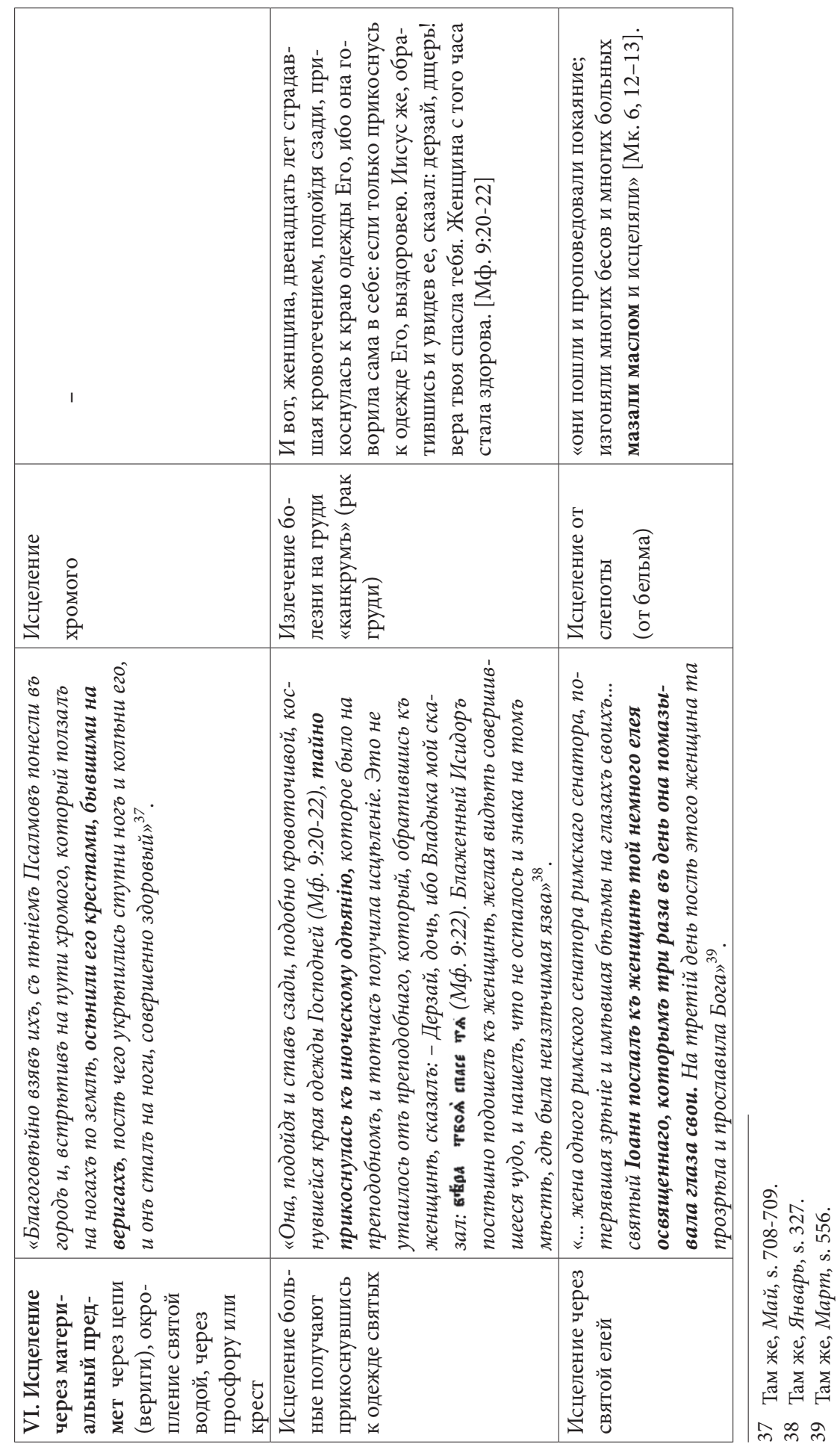




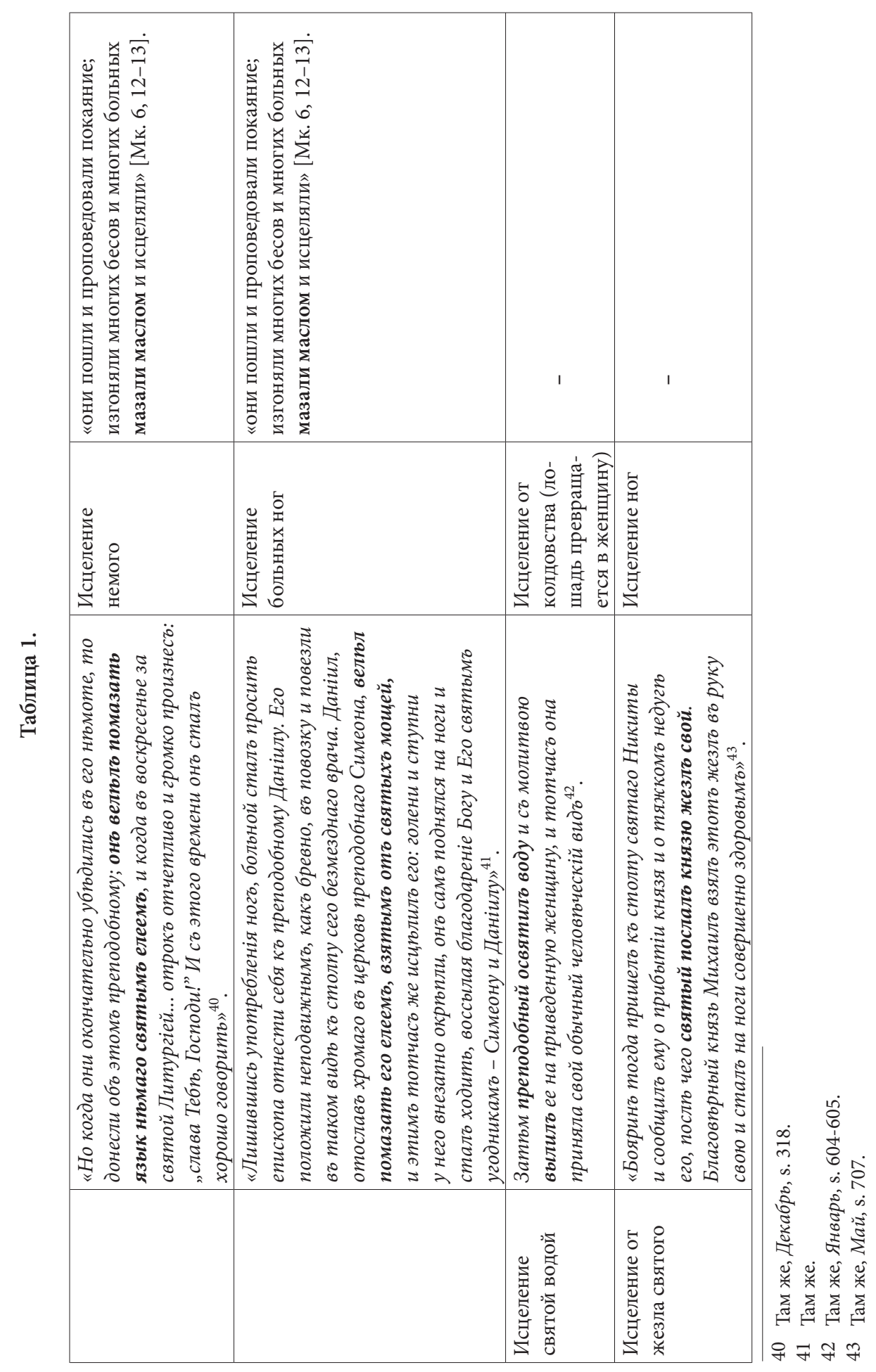




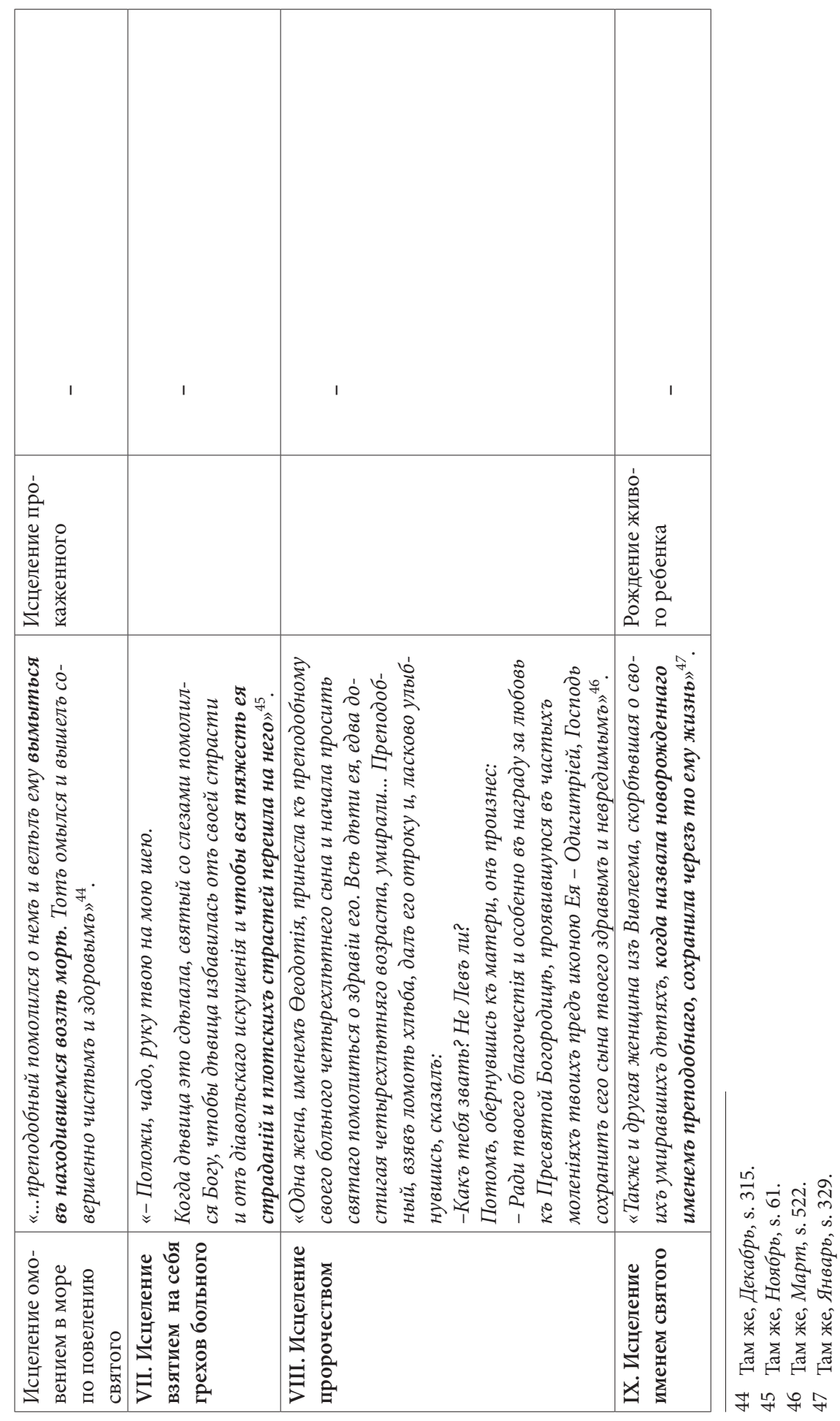


Как видим, в описании продолжительного лечения текст содержит более или менее значительное количество подробностей, хотя в целом. В житиях святых очень скупо описана болезнь и сам процесс исцеления. Следующее житие, как и более поздние жития характеризует большая описательность. Агиограф в описании чуда приводит больше подробностей. В житии святого Серафима Саровского, который жил в середине 18 в начале 19 века, описан эпизод чуда исцеления. Агиограф указывает дату - 1823 год и реально жившего человека - помещика Ардатовского уезда М.В. Манторова из имения Нуч. Агиограф приводит описание болезни: «... болящаго выпадали даже кусочки кости изб ногъ и всякая надежда на медищинскую помощь была потеряна» ${ }^{48}$. Больного внесли в сени кельи старца и святой спросил, верует ли он в Бога. Больной троекратно заверил святого, что он верует. Тогда старец ласково сказал: «- Радость моя! если ты такъ вируешь, то върь и въ то, что впрующему все возможно отъ Бога, а посему впруй, что и тебя исиьллит Господь, а я, убогій Серафимъ помолюсъ» ${ }^{49}$. Далее агиограф пишет, что старец удалился в келью и немного времени спустя вернулся. Автор упоминает, что святой молился перед иконой Божьей Матери «Умиление» и вынес святой елей из лампадки, помазав ноги больного, и «тотчасъ же струпья, покрывавщіе тюоло, мгновенно отпали, и Манторовъ получиль исциленіе» ${ }^{50}$. В описанной ситуации человек болел долго, а излечен мгновенно. При этом сам процесс подготовки к исцелению описан подробно. Как видим, подробности описания чуда исцеления - это не только применение детализации, указание точных сведений о месте, времени, имени исцеляемого, это описание процесса исцеления. В любом случае подробности существенно усиливают эффект реальности, делают описание чуда более убедительным.

Святые, которые в житиях описываются как субъекты совершения чудес, совершают их по аналогии с теми чудесами, которые описаны в прецедентных ситуациях Священного Писания. Для описываемого святого, для автора Житий, для читателя Житий, Евангелие является наиболее значимым текстом, он имеет сверхличностный характер, обращение к нему возобновляется неоднократно, чему свидетельство сам текст житий. Поэтому некоторые описания чуда-исцеления в житиях является фактически отсылкой к Евангелию, своего рода цитатой или пересказом, упоминанием данной ПС в прецедентном тексте. Квазицитация отсутствует, что естественно для житий;

\footnotetext{
48 Там же, Январь, s. 96.

49 Там же.

50 Там же.
} 
т.к. святые, являютя последователями учения Иисуса Христа и не могут искажать ни его слов ни действий. Аллюзии также отсутствуют, в связи с тем, что текст житий должен быть простым для восприятия читателя или слушателя.

Действия святых из Житий чаще сопровождается глаголом помолился, тем самым подразумевая их обращение к Иисусу Христу и Божьей Матери.

Также рассмотрение описания чудес-исцелений в житиях святых отшельников, показывает, что при сравнениис ПС, из прецедентного текста (Новом Завете) видно, что в некоторых случаях совпадает и болезнь и процесс излечения. Однако в большинстве случаев в житиях святых название болезней увеличивается и процесс их излечения также трансформируется, новая болезнь может быть излечена как старыми методами, описанными в ПТ, так и новыми методами, вероятнее всего частично связанные с народными верованими и обрядами.

\section{Библиография}

Bakhtin M.M., Voprosy literatury i estetiki, Moskva 1975.

Bart R., Izbrannyye raboty. Semiotika. Poetika, 1994.

Bibliya. Knigi svyashchennogo pisaniya Vetkhogo i Novogo Zaveta, Rossiyskoye bibleyskoye obshchestvo, 2008, Moskva.

Bobyreva Ye.V., Religioznyy diskurs: tsennosti, zhanry, yazykovyye kharakteristiki, Volgograd 2007.

Bouflet J., Historia cudów: od średniowiecza do dziś, przeł. K. Żaboklicki, Warszawa 2011.

Gudkov D.B., Pretsedentnaya situatsiya i sposoby yeye aktualizatsii, [w:] Yazyk, soznaniye, kommunikatsiya, V.V. Krasnykh, A.I. Izotov (red.), Moskva 2000, s. 40-46.

Historia ciała, t. 1, Od renesansu do oświecenia, G. Vigarello (red.), przeł. T. Stróżyński, Gdańsk 2011.

Karasik V.I., Yazykovoy krug. Lichnost', kontsepty, diskurs, Volgograd 2002.

Karaulov Yu.N., Rol' pretsedentnykh tekstov vstrukture i funktsionirovanii yazykovoy lichnosti. Nauchnyye traditsii i novyye napravleniya vprepodavanii russkogo yazyka i literatury, Moskva 1986, s. 105-126.

Karaulov Yu.N., Russkiy yazyki yazykovaya lichnost', Moskva 2007.

Kostomarov V.G., Burvikova N.D., Kak tekstystanovyat.sya pretsedentnymi, „RYAZR” 1994, nr 1, s. 73-76.

Krasnykh V.V., Virtual'naya real'nost' ili real'naya virtual'nost'? (Chelovek. Soznaniye. Kommunika Kommunikatsiya), Moskva 1998.

Mechkovskaya H.B, Yazyk i religiya. Lektsii po filologii i istoriireligiy, Moskva 1998.

Novyy zavet, Evangeliye ot Ioanna, [online], http://www.patriarchia.ru/bible/jn.

Novyy zavet, Evangeliye ot Luki, [online], http://www.patriarchia.ru/bible/lk.

Novyy zavet, Evangeliye ot Marka, [online], http://www.patriarchia.ru/bible/mk.

Novyy zavet, Evangeliye ot Matfeya, [online], http://www.patriarchia.ru/bible/mf. 
Pleshakova A.V., Issledovaniye freymov "proisshestviye» na materialerusskikh i angliyskikh tekstov zhanra «informatsionnoye soobshcheniye», Diss. Na soisk. Zvaniya k.f.n., Saratov 1998.

Rastyagayev A.V., Zhitiynayatopika v proze pisateley XVIII stoletiya (Kantemir, Trediakovskiy, Fonvizin), Samara 2009.

Slyshkin G.G., Pretsedentnyytekt: struktura kontsepta i sposoby apellyatsii $k$ nemu, Problemy rechevoy kommunikatsii, Mezhvuzovskiy svorniknauchnykh trudov, Saratov 2000, s. 62-68.

Starodumov I.V., Zhanrovaya spetsifika povestvovaniy o posmertnykh chudesakh podvizhnikov $i$ sostave drevnerusskoy agiografii. Dis. na soiskaniye uch.stepeni kand.fil.nauk, Omsk 2009.

Usacheva V.V., Magiya slova i deystviya v narodnoy kul'ture slavyan, Moskva 2008.

Zhitiya svyatykh na russkom yazyke, izlozhennyye po rukovodstvu Chetix Miney svyatitelya Dimitriya Rostovskogo, v 12 t., izd. Imperatorskoy Akademiyey Nauk v 1789-1794 gg.

\section{Slovari}

БTC - Bol'shoy tolkovyy slovar' russkogo yazyka, S.A. Kuznetsov (red.), Sankt-Peterburg 1998.

HCPЯ - Novyy slovar' russkogo yazyka, T.F. Yefremova (red.), Moskva 2000.

CAP - Slovar' Akademii Rossiyskoy, Sankt-Peterburg 1789-1794, [online], https://www. runivers.ru/lib/book3173.

ХрЭС - Khristianstvo. Entsiklopedicheskiy slovar', t. 1., Moskva 1994.

МСДРЯ - Materialy dlya Slovarya drevne-russkogo yazyka Po drevnim pamyatnikam, t. 1, I.I. Sreznevskyy (red.), Moskva 1893.

ФЭС - Filosofskiy entsiklopedicheskiy slovar', Moskva 2000, [online], https://dic.academic. ru/dic.nsf/enc_philosophy/3699.

ЭтC - Maks Fasmer, Etimologicheskiy slovar' russkogo yazyka, t. 1, 1986, [online], http:// www.slovorod.ru/etym-vasmer/_pdf/vasmer-etymologic-dict1.pdf. 